\title{
E-Pilkada: Opportunities and Challenges in Indonesia
}

\author{
Eva Hany Fanida ${ }^{1}$, Indah Prabawati ${ }^{2}$, Muhammad Farid Ma'ruf ${ }^{3}$, Suci \\ Megawati $^{4}$ \\ (evafanida@unesa.ac.id ${ }^{1}$, indahprabawati@unesa.ac.id², \\ muhammadfarid@unesa.ac.id ${ }^{3}$, sucimegawati@unesa.ac.id ${ }^{4}$ ) \\ Department of Public Administration, State University of Surabaya, Jl. \\ Ketintang Surabaya ${ }^{1,2,3,4}$
}

\begin{abstract}
The Coronavirus Disease (Covid-19) pandemic creates a new life order, one of which is the use of technology to be a necessity, people are massively literate of onlinebased information technology, with the literacy of society in the use of technology to support the discourse of implementing the e-election system for elections in regional heads in Indonesia. This e-pilkada option is an alternative solution for regional head elections that is more affordable, faster, and more practical. On the other hand, implementing e-pilkada is not merely a matter of changing ballots to electronic ballots, but also about the validity and security of electronic transactions, legal products, infrastructure, public readiness, effectiveness of control mechanisms, and public awareness. Based on the data that has been mentioned above, a comprehensive study is needed on the opportunities and challenges of implementing electronic Pilkada (ePilkada)/ e-voting in Indonesia. Therefore, the aim of this research is to analyze the opportunities and challenges in the future of e-Pilkada in Indonesia.
\end{abstract}

Keywords: e-pilkada, e-voting, regional head election

\section{$1 \quad$ Introduction}

11 Regional Election Challenges during the Coronaviruses Desease (Covid-19) Pandemic With the passage of Government Regulation in Lieu of Law Number 2 of 2020, the government's decision to continue holding regional head elections (pilkada) in 270 regions on December 9, 2020 amidst the Coronaviruses Disease (Covid-19) pandemic is final. The Pilkada (election of local lader) is specifically intended to select 9 governors, 224 regents and 37 mayors simultaneously in Indonesia. One of the government's considerations to continue carrying out regional elections in the midst of the Covid-19 pandemic is the success of several countries, especially in Asia, which have held elections in 2020 amid the Covid-19 pandemic, such as Mongolia, Malaysia, Japan, Singapore and South Korea, albeit with various obstacles. Based on data from International Institute for Democracy and Electoral Assistance (IDEA), during the period 21 February 2020 to 19 July 2020, at least 23 countries have decided to postpone elections and national referendums. However, in the same period, 49 countries and territories 
have decided to hold national or subnational elections as originally planned, despite concerns over the Covid-19 pandemic. of these, at least 31 countries have held national elections or referendums. (Idea International "Global Overview of Covid-19: Impact on Elections".[1] The implementation of the Pilkada amid the Covid-19 pandemic is certainly a challenge in itself for the Indonesian government, because without the Covid-19 pandemic alone, the implementation of the elections in normal conditions still brings various problems such as low levels of participation or money politics, violations of campaign stages and law enforcement.[2] Meanwhile, during a pandemic the problem will become more complex, such as:

a. Potential threats to the health and mental safety of the public, election participants and organizers. In the pilkada during a pandemic, the Election Supervisory Body (ESB) does not only supervise the implementation of the pilkada. However, supervisors must also ensure and supervise the implementation of the Covid-19 health protocol in the regional elections.

b. Election financing budget. It was decided that the 9 December 2020 pilkada had to meet the prerequisites. One of them is a matter of budget availability. This is because the regional elections during a pandemic require the provision of personal protective equipment (PPE). This PPE is also intended for election organizers, both General Election Commissions (GEC) and ESB ranks.

c. Public participation. One indicator of quality elections is good public participation. But the challenge is that the regional elections during a pandemic can affect the inner situation of the community. This can have a strong impact on the participation of the community in overseeing the various stages of the elections. The role of the public is not only on voting day but at all stages. Based on data processed from International IDEA, the level of voter participation in countries holding elections during the Covid-19 pandemic, on average, has decreased compared to the previous election. The majority of countries holding elections during the Covid-19 pandemic are facing this problem of low voter participation.

Table 1. Comparison of Voter Participation Rates During and Before the Covid-19 Pandemic

\begin{tabular}{ccccc}
\hline Country & $\begin{array}{c}\text { Type of } \\
\text { Election }\end{array}$ & Date & $\begin{array}{c}\text { Participation } \\
\text { Number }\end{array}$ & $\begin{array}{c}\text { Previous } \\
\text { Election }\end{array}$ \\
\hline Iran & Parliament & February 21st 2020 & $42.32 \%$ & $60.09 \%$ \\
Dominican Republic & President & March 15th 2020 & $55.18 \%$ & $67.77 \%$ \\
Vanuatu & Parliament & March 19th 2020 & $51.29 \%$ & $56.47 \%$ \\
Guinea & Parliament & March 22th 2020 & $58.04 \%$ & $63.53 \%$ \\
Queensland & Local Election & March 29th 2020 & $77.78 \%$ & $83 \%$ \\
Mali & Parliament & March 29th 2020 & $35.58 \%$ & $38.50 \%$ \\
South Korea & Parliament & April 15th 2020 & $66.21 \%$ & $58.03 \%$ \\
Serbia & Parliament & June 21st 2020 & $48.93 \%$ & $56.07 \%$ \\
Iceland & President & June 27th 2020 & $66.92 \%$ & $75.67 \%$ \\
Croatia & Parliament & July 5th 2020 & $46.90 \%$ & $52.59 \%$ \\
Singapore & Parliament & July 10th 2020 & $95.81 \%$ & $93.70 \%$ \\
Poland & President & July 12th 2020 & $68.18 \%$ & $55.34 \%$ \\
\hline
\end{tabular}

Based on Table 1, it can be seen that in general, almost all countries that held elections during the Covid-19 pandemic experienced a decrease in public participation compared to the elections 
before the Covid-19 outbreak. However, among the 12 countries, there were 3 countries that actually experienced an increase in the number of voter turnout, namely South Korea, Singapore and Poland. [1]

d. Increasing money politics. Under normal circumstances, money politics can flourish. Especially in the midst of a pandemic situation which causes the economy to slow down. Voters can become targets of certain parties who practice money politics. Do not use money as an approach to the voting society.

e. The politicization of budget programs and abuse of positions and powers. Government assistance programs that are supposed to be used for the benefit of the community but some are used by politicization for political interests. Including the existence of the non-neutrality of the State Civil Service (SCS).

f. The rampant misappropriation of social media. Due to the covid-19 elections, many activities were carried out by using technology. Communication and coordination patterns shifted from manual to digital. Included in the campaign stage. If it is not used responsibly, there will be misuse of social media. In the normal era elections, there are many hoaxes on social media, especially if the era uses social media a lot.

g. The quality of the election administration. The Pilkada should not only be carried out but the quality is really maintained. Pilkada should not be just perfunctory. We must not ignore the quality of the selection. Bawaslu hopes that all components in Central Java will maintain the quality of the 2020 regional elections.[3][4]

h. Campaign that is not easy for prospective pilkada participants. In an abnormal situation like today, campaign elements for candidates or pilkada participants are not easy. The time was difficult and the situation made it impossible for the candidate to gather the masses. In fact, the campaign in the electoral process in Indonesia is synonymous with mass gathering. With a symbolic type campaign arrangement, where candidates will tend to mobilize the masses, while there is a policy of limiting the masses in public areas, one of which regulates physical distancing or social distancing, of course this is not easy for prospective pilkada participants.

\section{$2 \quad$ Methodology}

This research is an exploratory research, which is research conducted to explore data and further research. The research objective is to formulate more accurate questions that will be answered in further research or later research. Researchers usually use exploratory research to gain sufficient knowledge in designing and implementing more systematic follow-up studies. Exploratory research is generally carried out to answer the question "What" (What exactly is this phenomenon?). The purpose of this exploratory research is to map and examine issues of various research results with the theme of e-voting. In this study, it was determined that the source of information was the result of research related to e-voting which was taken from both journals and online literatures.

The research model used is systematic literature review. The research begins by determining the search keywords, then searching the data through the predefined search engine applications. Based on a brief study (title, abstract and conclusion) of each article taken, data were grouped based on two dimensions, namely the dimension of opportunity and the dimension of challenge and the research method used. 


\section{$3 \quad$ Finding and Discussion}

\subsection{Electronic Pilkada (E-Pilkada) or E-Voting Opportunities During The Covid-19 Pandemic}

The socio-economic situation in the community is the main focus in the midst of a pandemic that has not yet subsided. Various problems in the socio-economic life of the community have also begun to emerge. The implementation of Pilkada this year has also experienced problems, namely that the community has to choose a candidate for leadership, but there is still a pandemic that continues to stalk the level of public health, so the concept of Pilkada is needed that can protect people by voting rights and from Covid-19 attacks. The concept of Pilkada simultaneously becomes an urgency that must be carried out while adhering to health protocols. Although this is not enough, because when the Pilkada is held simultaneously it will still invite the crowd. Therefore, there is an opportunity for this e-voting to be implemented in the 2020 Pilkada simultaneously or in the next election / regional election, namely by carrying out application-based electronic elections (e-pilkada). E-voting is a method of voting and counting votes using electronic devices. Even with the rapid development of the internet, e-voting can be integrated with the internet. Furthermore, based on research result of Fanida, et.all (2020) which has been published in Journal of Advances in Social Science, Education and Humanities Research, it can be known that the process of voting and counting votes in real time will allow the results of the vote count quickly and accurately, and provided there are no multiple voters. [5] Voter card validation can be done by collecting data on electronic civil card (e-KTP) as a database for Permanent Voters Data (PVD). [6]

The opportunity for the implementation of E-Pilkada has also been further strengthened by the existence of rules for electronic voting (e-voting) as stipulated in Law Number 10 of 2016 concerning Second Amendment to Law Number 1 of 2015 concerning Stipulation of Government Regulations in Lieu of Law Number 1 of 2014 concerning the Election of Governor, Regent and Mayor into Law. Article 85 paragraph (1) states that voting for elections can be done by:

a. put 1 mark on the ballot paper; or

b. voting through electronic voting equipment.

However, paragraph (2a) states that electronic voting is carried out by considering the readiness of the regional government in terms of infrastructure and the readiness of the community based on the principles of efficiency and ease.

Based on the explanation above, it can be seen that technology is here to assist in every step and human movement in real work, but infrastructure support in developing technology must also be balanced with the quality of competent human resources. [7] [8] Democracy as a way to get leaders who are pro to society should not be stopped due to the pandemic. The concept of e-voting is a solution and urgency for Pilkada organizers and the Central Government, as well as Regional Governments to work together in realizing quality Regional Head Elections.

\subsection{Advantages of e-Pilkada / e-Voting}

According to the International Institute for Democracy and Election Assistance (IDEA), which is an intergovernmental organization that supports the continuation of democracy around the world, electronic voting is often seen as a tool to make the electoral process more efficient and to increase trust in its administrators. Properly executed, e-voting solutions can increase 
ballot security, speed up processing of results and make voting easier.[9] However, the challenges are worth being reckoned with. If not carefully planned and designed, e-voting can undermine confidence in the entire electoral process. Furthermore, Sunberg (2019) on Journal of Safety Science also said that the policy sheet outlines the contextual factors that can influence the success of an e-voting solution and highlights the importance of the following before choosing to introduce a new voting technology.[10]

Based on results research of Centinkaya, et.all (2007) which have been published in The Electronic Journal of e-Government that e-voting refers to the use of computers or computerized voting equipment to cast ballots in an election.[11] It can be concluded that e-voting is the implementation of voting conducted electronically from the voter registration process, candidate registration, election implementation, vote counting, and voting results delivery. The application of e-voting is expected to solve the problems that arise from conventionally held elections. As mentioned by Riera and Brown (2003) and de Vuyst and Fairchild (2005) on Electronic Journal of e-Government that the benefits that will be obtained in implementation of e-voting. These benefits as an opportunity if e-voting is carried out include:

a. speed up vote counting,

b. the vote count results are more accurate,

c. save printed material for ballot paper,

d. save on ballot paper shipping costs,

e. provide better access for those who have physical limita tions (disabilities),

f. provide access for people who have limitations time to go to the polling station,

g. ballot papers can be made into various language versions,

h. providing access to more information relating to choice of sound,

i. can control parties who are not entitled to vote for example because they are under age or exceed the age of voters who are has been arranged. [12] [13]

According to the International Institute for Democracy and Electoral Assistance (International IDEA) which is then Gritzalis (2020) said that e-voting has prospects which is good if applied to a country because most countries believe that e-voting will be common in the coming decades and the choices in e-voting can satisfy voters because of its convenience.[14]

According to the International Institute for Democracy and Election Assistance (International IDEA), the advantages associated with e-voting include:

a. faster count and tabulation of votes,

b. results are more accurate because human error is excluded,

c. efficient handling of complex electoral system formulas that require laborious counting procedures,

d. improved appearance of complicated ballots,

e. increase the convenience for voters,

f. potential to increase participation and number of votes, particularly Internet voting,

g. more in tune with the needs of an increasingly mobile society,

$\mathrm{h}$. prevention of fraud in polling stations and during transmission and tabulation of results by reducing human interference,

i. improve accessibility, for example, using audio ballots for deaf voters by voting via the Internet, as well as voters who live at home and live abroad.,

j. the possibility of using a multilingual screen that can serve multilingual voters better than ballots.

k. the reduction of ballots damaged by the electoral system can alert voters to invalid votes (although consideration should be given to ensuring that voters can not vote if they do so), 
1. potential cost savings in the long run through saving polling worker time and reducing costs for ballot paper production and distribution. Cost savings through Internet voting: global reach with very little logistical expenditure. There are no shipping costs, no delays in sending the material and receiving it back.

m. Compared to postal voting, Internet voting can reduce the incidence of voting and family voting by allowing multiple votes but only the last vote counted and preventing manipulation by providing a deadline for incoming mail, through direct control of voting time.[2] [15]

According to the International Institute for Democracy and Election Assistance (International IDEA), apart from strengths, there are also weaknesses related to e-voting, including:

a. lack of transparency,

b. limited openness and understanding of the system for those who are not the expert,

c. lack of agreed standards for e-voting systems,

d. requires system certification, but not agreed certification standards extensively,

e. potential to violate election secrecy, particularly in the system who authenticate both the voters and the votes given,

f. risk of manipulation by insiders with privileged access to the system or by outside hackers,

g. the possibility of cheating by massive manipulation by a small group of people inside,

h. increased costs of both purchasing and maintenance systems e-voting,

i. increased infrastructure and environmental requirements, for example, in relation to power supply, communication technology, temperature, humidity,

j. increased security requirements for protecting systems voting during and between elections to the next including during transport, storage and maintenance,

k. lack of level of control by election organizers due to high dependence on vendors and / or technology,

1. the recount possibilities are limited,

m. the need for additional campaigns for voter education,

n. potential conflicts with existing legal frameworks. potential lack of public confidence in evoting based elections as a result of the above weaknesses. [2] [15]

\subsection{Weaknesses of E-Pilkada /E-Voting}

Although many countries have implemented e-voting, there are still many obstacles that must be overcome so that e-voting can run smoothly and produce products according to people's choice, and the results can be trusted by the whole society. These obstacles, among others, according to Gritzalis (2002), include:

a. Difficulty of changing national election laws. E-voting is a must accompanied by the existence of a complete and regulating legal umbrella clear about the application of evoting from the preparation stage to validation of voting results. If e-voting is to be implemented it means The current Election Law must be reviewed. As is regulated in Law number 32 of 2004 in article 88 reads: "Voting for regional head and deputy regional head elections is done by casting a vote on one of the pairs of candidates in the ballot".

b. Security and reliability of electronic voting. The safety and reliability of evoting are the most strategic issues in the application of e-voting. Although e-voting offers speed in calculations and distribution of vote count results but the validity aspect of the data must be upheld because it is closely related to the validity of the results Election. [16]

c. Equal access to Internet voting for all socioeconomic groups. Not all voters have access to the Internet if e-voting is conducted based online because of the heterogeneity of society 
and existence digital divide. If e-voting is done through DRE where are the voters must come to the polling station, the constraints of low literacy in use Information technology is very likely to hinder the implementation of e-voting. [4]

d. Difficulty of training election judges on a new system. Not only the voters and organizers who must be ready for e-voting, witnesses and supervisors must have IT literacy. Therefore it must be held training for witnesses and election supervisors so that if problems arise in the implementation of elections to have competence to solve it.

e. Political risk associated with trying a new voting system. There is a risk politics towards the implementation of e-voting and this is very much related to the validity of the election results. If the election fails to take place, there is a risk a very large impact on the political instability of a country.

f. Need for security and election experts. The implementation of e-voting is necessary information technology security expert and understand the system at the same time election. In reality it is very difficult to recruit a lot of personnel who are experts in information technology security and at the same time master electoral system. [7]

From the explanation above, it is explained the advantages and disadvantages of e-voting, so of course the e-voting system in the 2020 Pilkada requires thorough readiness from the side of the organizers and also from the side of the community, as well as in terms of internet infrastructure. Human resources also require more mature socialization with the help of training using the e-voting system which is run through cloud computing facilities. By using cloud computing, training can be carried out cheaply and in bulk. Henceforth, e-voting can be implemented in stages. For example, the easiest step is to create a hybrid solution using a paper voting system, but it is supported by the use of cloud computing technology in the processing department. Henceforth, slowly all the processes that occur in the general election can implement digitalization in stages. The community is expected to be more easily involved in the democratic party, and gradually the public's trust in technology will increase. Along with this increase in trust, trust in the e-Voting system has also increased. That way, gradually the application of e-voting in every general election will be more comprehensive and can realize elections that are transparent, fast, effective, and inexpensive.

\section{Conclusion}

Even though the e-voting concept has not been implemented in a democratic party, of course this can be a consideration for the implementation of the Pilkada in the midst of the Covid-19 pandemic. Apart from not inviting crowds, this concept will certainly increase the level of efficiency and effectiveness in an electoral system. However, there are still weaknesses that must be anticipated. Weaknesses in the e-voting system, namely in terms of security. Cyber Security in the e-voting system must protect from various cyber attacks that can damage network security systems and data systems. The era of Big Data has opened the minds of all of us, that in information system technology is not only a tool but stored data that will make a decision or policy in determining something. Likewise in the concept of e-voting, the main thing that must be validated is related to voter data. Because the statistical calculation of numbers will cause polemics, if the initial data is unsynchronized with the election result data. Hopefully the idea of the Electronic Pilkada (E-Pilkada) can be taken into consideration in the implementation and implementation of the 2020 Pilkada Simultaneously, and will not cause any hiccups in the democratic process in Indonesia. 


\section{References}

[1] Hamzah, Hardiansyah, "Pilkada vs Pandemic, and Experience Of Other Countries," 2020.

[2] S. A. Adeshina and A. Ojo, "Factors For E-Voting Adoption - Analysis Of General Elections In Nigeria," Gov. Inf. Q., no. November 2015, pp. 1-12, 2017.

[3] A. Zwierko and Z. Kotulski, "A Light-Weight e-Voting System with Distributed Trust," Electron. Notes Theor. Comput. Sci., vol. 168, no. SPEC. ISS., pp. 109-126, 2007.

[4] M. Warkentin, S. Sharma, D. Gefen, G. M. Rose, and P. Pavlou, "Social identity and trust in internet-based voting adoption," Gov. Inf. Q., vol. 35, no. 2, pp. 195-209, 2018.

[5] Fanida, E. H., D. Manda, and M. Mandagi, "Electronic Voting (E-Voting) in Indonesia: Reflection On E-Voting Practices in Some Countries," vol. 226, no. Icss, pp. 150-155, 2020.

[6] C. Bouras, N. Katris, and V. Triantafillou, "An electronic voting service to support decision-making in local government," Telemat. Informatics, vol. 20, no. 3 SPEC., pp. 255-274, 2003.

[7] V. Fedorov, "Electronic voting and democratic transit," no. July, pp. 0-12, 2020.

[8] E. Aljarrah, H. Elrehail, and B. Aababneh, "Computers in Human Behavior E-voting in Jordan : Assessing readiness and developing a system," Comput. Human Behav., vol. 63, pp. 860-867, 2016.

[9] J. Wang, H. Wang, M. Zhao, J. Cao, Z. Li, and M. Guo, "Joint Topic-Semantic-aware Social Matrix Factorization for online voting recommendation," Knowledge-Based Syst., vol. 210, p. 106433, 2020.

[10] Sundberg, L., "Electronic Government: Towards E-Democracy or Democracy At Risk?," Saf. Sci., vol. 118, no. April, pp. 22-32, 2019.

[11] Centinkaya, O., \& Cetinkaya, D, "Verification and Validation Issues in Electronic Voting." The Electronic Journal of e-Government, vol. 5, no.2, pp. 117-126, 2007.

[12] Riera, A., \& Brown, P., "Bringing Confidence to Electronic Voting," Electronic Journal of e-Government, Vol. 1, No. 1, pp. 14-21, 2003

[13] De Vuyst, B., \& Fairchild, A,"Experimenting with Electronic Voting Registration: the Case of Belgium," The Electronic Journal of e-Government, Vol. 2, No. 2, pp. 87-90, 2005.

[14] Gritzalis, D. "Secure Electronic Voting; New Trends New Threats," Athens: Dept. of Informatics Athens University of Economics \& Business and Data Protection Commission of Greece, 2002.

[15] IDEA, "Policy Paper Introducing Electronic Voting: Essential Considerations," International, Stockholm, 2011.

[16] D. Zissis and D. Lekkas, "Securing E-Government And E-Voting with an Open Cloud Computing Architecture," Gov. Inf. Q., vol. 28, no. 2, pp. 239-251, 2011. 